\title{
When "Sexuality" Floated Free of Histories in South Asia
}

\section{INDRANI CHATTERJEE}

$\mathrm{F}$ Rom the 1960s to the Present, scholars of Sanskrit, Tamil, Telugu, Bengali, and other regional literatures and cultures have spelled out their differences with either their Freudian or Foucauldian counterparts on the articulation of love, desire, and embodiment in these literatures (Alter 1997; Benton 2006; Dimock 1966; Doniger 1973; Doniger and Kakar 2002; Kakar 1989; Kakar and Ross 1986; Ramanujan 1981; Ramanujan, Rao, and Shulman 1994; Stoler Miller 1977; Sweet 2002; Wujastyk 2005, 2009; Zysk 2002). The subcontinent's textual cultures, they argue, interrogate Freudian notions of human personality as rooted in the "truth" of sexual desire. These scholars placed the study of erotica and the sciences pertaining to human bodies within structures of teaching-learning with very long historical pedigrees.

Discourses on embodiment practices were wrapped up in arguments about the multicorporeality and health of the human body, the cultivation of transcendence, and the physical display of perfection of control as a mark of "nobility." Pronouncements on desire, its domestication by various means, its locations in households of different kinds, and its ephemeralization were all part of a larger study of the human body as the seat of consciousness. Between the first millennium BCE and the thirteenth century CE, such study of human embodiment and consciousness occurred in lineages of students and teachers who were tied to each other by a preliminary ritual of consecration and initiation (diksa). These initiations set up a direct face-to-face hierarchical relationship between teacher and student, and admitted the student to a fraternity of fellows and into a hierarchical lineage of a chain of teachers who had taught his teacher. Scholars of Yoga and Tantra find that many of the teachers among Saiva, Buddhist, and Jaina monks were also employed as official sorcerers, healers, and magic practitioners by local rulers and "big men" (Davidson 2002; Samuel 2005, 2008; White 1996, 2003, 2009).

From this proximity between monks, ascetic-warriors, and "big men" arose a form of governance we can identify as "monastic governmentality" in South Asia. Unlike Foucauldian "governmentality," which expressed the conduct of a bourgeois Liberal European state after the seventeenth century, Indian monastic 
governments were territorially limited by charters of the grants of land and tenants to cultivate them; particularized by ritualized initiation-consecration, ordination, and mind-body exercises (yoga, mantra, and tantra); and dependent on the numbers of adherents and subjects that adhered to each teaching lineage. Each was both limited and collocated with others in a patchwork of jurisdictions. Each monastic government addressed itself to a variety of audiences by deploying different languages; the more esoteric and metaphysical were limited to an inner circle of initiates, while a more literal or transparent style of communication was directed towards lay audiences and adherents. These forms of monastic governments and communication also elevated the status of the adept teacher-guru to near-divine status (Das 1992).

Far from the European Protestant disgust with intermediaries evident from the fourteenth century, subcontinental medieval monastic academies remained focused on the production and licensing of experts to mediate between the unlettered and the skilled. As the examples from Tibetan and Nepali histories illustrate, teachers and polyglot translators were political actors from the seventh to the seventeenth century. Furthermore, since consecrated and lay students both learned from the same teacher, the latter's philosophies informed both the esoteric ritual texts and the erotic poetry composed by the students belonging to the same order. Hence both poetry (mantra) and ritual means (tantra) were fundamental to the training of medieval courtiers (D. Ali 2006). Many women were patrons of such lineages, and some were ordained members as well.

Furthermore, if studies of medieval Kashmiri scholars are at all indicative, the same Saiva disciple-scholar who wrote weighty grammar and commentary in Sanskrit could also write "history" placing Buddha in a genealogy of Visnu (Cattoi and McDaniel 2011; Flood 1993; Nadou 1980), as well as discuss the comparative advantages of a "third gender" (trtiya prakrti) person over a female lover (Baldissera 2009). Monastically trained literati, such as Ksemendra in the eleventh century, apparently appreciated the perspective of the male lover of such third persons, for he even wrote of their advantages when it came to lovemaking: they could be clasped tighter for not having breasts, they offered no menstrual disruptions, and they suffered no diminution of beauty by pregnancy! If this is proof that medieval Hindu-Buddhist male courtiers had no problem imagining same-sex pleasures along with heterosexual pleasure, it must also be remembered that such discourse was usually part of polemics as well. Both tropes were part of the poetic critique of kings (Cox 2010). Both were implicated in the debate between Tantric and non-Tantric practitioners among the Buddhist, Saiva, Vaisnava, Jain, and Sufi-Baul communities. In other words, explicit invocation of bodies, desires, appetites, and signs constituted the foreground of a larger politics at work.

Foucault overlooked these aspects of the past of discourse. But the process he described in The History of Sexuality (1978)—the process of naming 
something as "sexual" — was fundamentally the process of European colonialism in non-European worlds from the sixteenth century itself. When Spanish Catholics encountered Andean ritual specialists (tinkuy), they described them as "sodomites" (Horswell 2005). An identical move occurred in India between the late eighteenth and nineteenth centuries, when revered tantric warrior-priests, merchants, and Sufi Muslim stewards of treasuries (khwajaserais) were all reduced to being "eunuchs" (Chatterjee 1999a, forthcoming). Through the nineteenth and twentieth centuries, British colonialism marginalized monastic governmentality, replacing it with corporate and parliamentary institutions, codes, and constitutionalism. Those ascetic-monastic lineages that survived the rebellion of 1857 had their fates sealed finally in 1872, when they were described as "criminal tribes" and their leaders were described as "eunuchs." Colonial despoliation of monastic governments was presented-and consumed by interested Indian laymen-as a form of secular Liberal governance. As this version of "Indian secularism" began to take shape, epistemologies, grammars, poetics, and practices specific to many of the defeated Tantric Buddhist, Bon-po, Jaina, Vaisnava, Saiva-Sakta, and Islamic monastic lineages were transformed from political codes of their own to sites of "sexuality."

These transformations were important because they marked the onset of a discursive colonization from which neither the colonized nor the colonizers recovered. The success of this discursive colonization rested on material despoliation; the latter in turn delegitimated the colonized natives' aspirations towards ritual fullness. Where the British colonial judicial and revenue regimes were concerned, the cultivation of such fullness could only be assessed as "sexuality" devoid of its multiple associations. Besides, the discourse of "sexuality" also obfuscates this very history by implying a commonality of pasts across space and time. This is patently an error. The direct experience of British colonialism makes the South Asian case vastly different from even that of adjacent polities and cultures in Southeast Asia (such as Thailand in the nineteenth century) or the Qing regime in China at the same time. In South Asia, British colonialism secured the legal permanence of conjugality and monogamous heteronormativity, and criminalized all other forms of attachment, embodiment, and livelihood. Above all, it was significant in objectifying "gender and sexuality" in dimorphic terms.

\section{Colonialism and the Seduction of "Sexuality"}

In the early twentieth century, some Indian scholars were aware that something dramatic had transpired in the intervening century. Iravati Karve, an Indian female anthropologist trained in Berlin in the 1930s and writing at the behest of academic friends in the United States, sought answers in texts held up as "history" in many societies of that time. This was the epic Mahabharata. But she looked at 
this text for an analysis of kinship, and she titled her own study of the epic Yuganta: The End of an Epoch (Karve 1969). On the other hand, her contemporary, the German Indologist Johann Jakob Meyer, who had published a study of the identical text in 1952, republished it with the title Sexual Life in Ancient India (1971). Meyer's reading of the text may have been part of a larger development of biological sciences in Germany in the first half of the twentieth century. It also contained a suggestion that early subcontinental societies had had a wider variety of sexual arrangements than was imaginable in the northern hemisphere. Its republication also coincided with a growing interest in matters of sexual liberty in a post-1968 moment, when anti-war, civil rights, youth, and feminist movements all occurred simultaneously in Europe and the United States. In these European and North American movements, the notion of liberty was very closely wedded to the issue of sexual liberation from the dogmas of the Christian church, the church fathers, and the patriarchs of civil society in the arguments of a majority of white, middle-class young men and women. The emergence of North American Liberal feminism in particular was premised on such an understanding.

A widely influential text from the latter was The Female Eunuch (Greer 1970), which argued that the "traditional" suburban, consumerist, nuclear family repressed [all] women's sexuality and rendered them into devitalized eunuchs. Greer's interpretation of androgyny rendered it, and transvestitism, synonymous with impotence and powerlessness in the world. Whether or not she was aware of the venerable status of androgyny in societies influenced by Himalayan and Inner Asian Buddhist (Gyatso 2003), Jaina, and Sufi mystic practices (Kugle 2007, 2010), or of the great popularity of theatrical transvestismwhen women acted in male roles and men acted in female ones-in nineteenthcentury subcontinental cultures (Hansen 1992, 1999, 2004) was never at issue. Yet her manifesto was a call to all women to reclaim their "libido," their faculty of desire, from which they had apparently been separated.

There were many ironies implicit in such calls. For one, this language of consumption rested on an invisible philosophical correspondence between dimorphic physical bodies and the maleness or femaleness of personality. This was certainly not how bodies were either imagined or studied in South Asia before the eighteenth century. A vast literary and aesthetic corpus spoke of adulterous erotic yearnings of mutably gendered beings, of gods who came as ordinary customers to haggle over a courtesan's fees, of the enjoined feminization of all biologically male devotees of Krsna or Siva. Themes of sexual indeterminacy bound eastern Indian Vaisnava poetics from the sixteenth century (Hawley 1988) to their Sufi counterparts in Panjab and the Deccan (Petievich 2007) well into the late eighteenth century. There was certainly no hegemonic idealization of heterosexist conjugal being or pathologies of dimorphic sexual personalities. Yet these ideas had been institutionalized by the power of colonial-era law, and the seductions of colonially generated goods and markets. 
The call to fulfill sexual appetites (or desire) as a fundamental program for social "liberation" consolidated the histories of Liberalism, first institutionalized in colonial legal codes during the nineteenth century and then by Liberal feminist calls in the mid-twentieth century. Thus the Liberal feminist exhortations of Our Bodies Ourselves (Boston Women's Health Book Collective 1973) appealed to an especially well-prepared minority of young men and women in metropolitan colleges in 1970s India. Presumably similar minorities of young men and women were attracted to the same ideologies in Pakistan (Zafar 1991), Bangladesh (Kabeer 1985), and Sri Lanka (De Mel 2001) at the same time. Each of these colonially shaped land-masses and governments had its own historical trajectory and deserves more attention than can be given them here.

A focus on India alone during these decades may prove suggestive, however. Indian secondary education had come into its own in these decades due to the commitments of the postcolonial Nehruvian state to expanding the gains of colonial-style medical, engineering, and scientific education to a state-made technocratic middle class. British colonial regimes had only invested in women's "domestic science" education, and the Nehruvian state largely continued the process. It was these female students who were handed the non-governmental, and chaotically disorganized, task of "care-giving" to a postcolonial nation-in-the-making from the 1970s.

As the histories of the first Indian women's groups (Kumar 1993) reveal, local populations often called upon them to "put a Band-Aid" on unsustainable domestic arrangements (Vanita 2005b), to provide assistance in crisis. These young female students in postcolonial universities embraced transnational, Liberal, Anglo, feminist teachings as their own because their explanations offered a frame for comprehending a historic violence all around them since the Second World War and especially acute in the 1960s-70s. However, the difference between these postcolonial Liberal feminists and their Anglo counterparts was that the former were less concerned with themselves than they were with the alleviation of others' suffering.

The simultaneous opening of the Indian markets in the 1980s, the discovery of AIDS-related deaths in Europe and the United States, and the declaration of 1985 as the International Year of Women by the United Nations made such suffering a source of concern. The nexus of domestic and global suffering generated the earliest sociological-historical studies of groups who had been traumatized. The earliest studies therefore tracked the misfortunes of those skilled artists, the temple-attached dancers, songstresses, and their entourages who were disempowered and dispossessed by a collaborative native-colonial lay patriarchate in the twentieth century. Begun by Amrit Srinivasan's (1985) pioneering study of Southern India, this trend remained productive until the present (Soneji 2011). It influenced the analysis of identical transformations wrought by colonial-era Contagious Diseases Acts of 1864-88 in various parts of the subcontinent, such as the princely state of Mysore (Nair 1994) and the colonial capital, 
Calcutta (Banerjee 1998); of colonial legal regimes in Maharashtra (Jordan 2003); and of the colonial misgovernment of the commercial capital of Bombay-Mumbai (Tambe 2009) in particular.

Halfway through this decade, a subtle shift in naming became noticeable in the scholarship. Historians of the Indian subcontinent had been probing sociopolitical institutions of various kinds since the 1980s. But only in the 1990s did they begin to call their work studies in "sexuality" (compare Kadam 1988 with Chakravarti 1995; Uberoi 1996). Common to all of their concerns, however, was a focus on the ways in which the pluralities of heterosexual arrangements among both Hindus and Muslims, the wealthy and the rural middling groups of farmers and tenant peasants, had been domesticated so that all groups alike were primed to follow a model of patrilineal households resting on a monogamous heterosexual order. Specially noteworthy in this regard were the studies of the ways in which polygynous, polyandrous, and levirate forms of heterosexual cohabitation, female headship, and avunculineal systems of property transmission were reconstituted in their encounter with British colonial norms and strictures. The elder women in the Muslim ruling households were defeated first by a wave of colonial military patrilinealization of family and community forms (Barnett 1998; Fisher 1998). Then they were followed by other groups (Arunima 2003; Chatterjee 2004; Chowdhury 1994, 1996; Poonacha 1996: Rege 1996; Sreenivas 2008). All these investigations revealed colonial judicial regimes keen to delimit the nature of descent to "heirs of the body," an increasing pathologization of sexual identity by genital characteristics (Srivastava 2004), and increasing attachment of the physical body to assessments of worth, such as masculinity (Sinha 1995), valor, and "legitimacy."

If this scholarship could be faulted, it was in the insufficient attention it paid to the emergent insights of art historians working with early South Asian materials. Art historians (Dehejia and Harnisch 1997; Desai 1997; Punja 1992, 1999) had revealed aesthetic and sculptural codes vastly different from that of the early nineteenth-century British collectors who stumbled upon the erotic art of the subcontinent. These feminist art historians pointed out that a sculpture with a flaccid penis represented enlightened super-males such as a Buddha or a Jina. An erect phallus represented a divine Siva. A non-muscular male Indian body represented a yogic (and idealized) balance of breath, energy, and flesh. Insufficient attention to art historical studies limited the first generation of feminist scholars to a narrowed understanding of "text" and "discourse." It also entailed ignorance of coeval lesbian feminists (Thadani 1996), who had analyzed evidence from identical sculptural material culture to establish the same argument as the documentary historians: there had been a considerable reconstitution of gynefocal traditions, divinities, and genealogies as androcentric ones. Yet both kinds of historians ignored each other.

Traumatic communal conflicts over material sites and cultures in the 1990sthe destruction of a mosque (1992), the attack on a film (1998)—thus caught both 
Liberal and Socialist Anglophone feminist scholars in the subcontinent on the wrong foot. They turned from the analysis of Anglophone discursive regimes to explorations of "nationalist" Hindu rhetoric (Burton 1999) and the latter's discourses on chastity and obscenity (C. Gupta 2001; Sarkar 2010). On a parallel track however were produced studies of nationalist Muslims who had also remade "respectable" Muslim femininity in India (A. Ali 2000; Amin 1996; Lambert-Hurley and Powell 2006; Minault 1998, 2009). Such studies, even though formally committed to the notion of "reconstituted" heterosexual, monogamous, conjugal, and patrilineal orders, generally valorized this reconstitution as progressive "reform." Yet it could not fully explain the sources of many of the ideas around the body, reproductive sexuality, or companionship that had clearly affected all sectarian and middle-class identities in the subcontinent. This absence in turn spurred on another group of historians. Some among them investigated Mughal and Rajput households between the fifteenth and eighteenth centuries (Balabanlilar 2010; R. Lal 2005; Sreenivasan 2006, 2007). Others, drawing on older scholarship (Visram 1986), reinvestigated eighteenth-century households of ordinary English officers and soldiers in the colonies (Chatterjee 1999b, 2004; Dalrymple 2002; Ghosh 2006; Hawes 1996). The goal was to understand the political-economic sources of early colonial natalist politics, to figure out why heterosexualization had rapidly overtaken lay and ordained households alike in colonized South Asia. As Chatterjee (1999b) and Sreenivasan (2004, 2007) found, Indian and British household types differed in their use of female and male slaves. Wills left by eighteenth-century British men suggested the centrality of Indian female slaves in the making of colonial codes of inheritance laws and property regimes. Thus indirectly, it could be seen, the Atlantic economies had been a significant factor in the "globalizing" of particularly raced, classed, and sexed "domesticity" in Indian households.

Conjugating romantic_-and orgasmic-heterosexual relationships to South Asian economic units that had hitherto organized work, subsistence, and giftgiving, i.e., the household, was part of the same "globalizing" process (Wilson 2011). Coeval poetic, satiric, and other literary-aesthetic products of the eighteenth and nineteenth centuries suggested that poets rooted in the older order continued to view passionate "love" as a mysterious affliction. In many instances, poets and monastics also allegorized such erotic and passionate love as "bondedness." However, colonial administrators and their newly found lay allies turned on these monastics and poets through the eighteenth and nineteenth centuries. They tamped down on rival ascetic warrior-merchant communities-the gosains and the bairagis (Kasturi 2009; Leonard 2011; Pinch 2006). Succession to authority and property among such ascetic and tantric yogic communities had proceeded, as they had among skilled dancers and musicians in the temples, by entirely nonsexual means in precolonial contexts. In the colonial nineteenth and twentieth centuries, some of these groups also appear to have succumbed to a reproductive sexual order of succession, and reconstituted 
themselves to keep pace with the pathologization of descent and inheritance systems in the world of householders.

Colonial-era legislation worked alongside colonial-era print-cultures to idealize the formation of conjugal heterosexual households on the basis of "love marriage" (Walsh 2004) and biological adulthood (from twelve years in 1891 to fourteen in 1929 and then eighteen in 2012). Legislation about the age at which sex was consensual was not aimed at preventing sex across the generational disparities of age, as it was to enable young men from the nascent Anglicized Indian merchant and clerical classes to overcome the authority of their generational and kinship elders and household heads (Newbigin 2010). Alongside generational authority was overthrown the caution about conjugality that some monastic codes had characterized as "spiritual snares" long before Liberal Anglofeminists warned against the pitfalls of heterosexual monogamy. But these monastic-authored erotic poetics were replaced by prosaic novels about "love." Twentieth-century brokerage institutions, caste-specific associations, and family firms that "arranged" marriages shored up a colonial-style "modern" conjugality as the only permissible form of social and sexual respectability (Bhattacharya 2005; Majumdar 2009).

Neither homo- nor hetero- "sexuality" simply existed in historical time and space: certain practices had to be defined as "sexual" before they could become "homo," "hetero," or "any-other-kind of sex." From the eighteenth century, a process of collaborative investments ensured that some practices and lineages were reinvested with "sexual" meanings. Plantation economies, commercial agriculture, and mining in the nineteenth century also redirected scholarly attention away from those lineages that had lost out. Once subject to colonial capital's mistranslation, the latter's histories became impossible to find. Only ethnographers in the 1990s found traces of life in some of those lineages swept off coveted lands from long ago; some have copied the leftover monastic governmental pattern of the past, complete with gurus and ritual initiations. But they subsist on the margins of urban Muslim and Hindu lineages as thirdgender beings. They are the hijras (V. Lal 1999; Reddy 2005) and kothis (Ramakrishna et al. 2004; Revathi 2005). They live in an ethnographic present. But nobody can quite explain the century-long process of their arrival at that marginal present.

Pointing this out is not to bemoan the linguistic losses of postcolonial scholars deprived of training in classical languages (Sawhney 2008). Nor is it necessarily to lament the spread of monoglot Anglophone cultures. English is doubtless a "modern" vernacular in the subcontinent. Yet it gives no access to categories and genealogies of thought prior to the sixteenth century. Like every other European language, it has no room for "it-ness" once valorized by Tantric Buddhists, Saiva, and Sufi-Baul alike. Pointing this out is to point to the much larger footprint that colonial, legal, Liberal epistemology has left on the Anglophone postcolonial scholar's practice. It is to argue that the successes of nineteenth-century 
colonial governments and capital have been maintained in the twenty-first century precisely by and within subcontinental feminist, queer, and postcolonial scholarship in global "gender and sexuality" studies. A representative of the latter thus sums up the dilemma precisely: "In queer circles today, it is almost absurd to question the idea that each simply has a sexuality-one that is somehow within the person, that is repressed by society and that needs to be expressed. In other words, the idea of sexuality has come to be naturalized, that is the relationship between the idea and the 'reality' has been placed beyond question. In turn this has meant that we now imagine our sexual universes in terms of types of people, who have different types of sexuality. This also means that we are driven to translate diverse sexual behaviors, desires and politics into language that finds its base in the idea of sexuality as personhood" (Khanna 2005, 93).

\section{Colonial Dimorphism and Postcolonial Feminist Historiography}

To be fair, this is not a condition specific to subcontinental activists alone. Rather, the very condition of "consumptive modernity" (Goswami 2008) or "passionate modernity” (Srivastava 2007) in a Liberal and postcolonial global present ensures that all people are studied only so long as essentialized identities can be attributed to them. It is the condition of professional social sciences at present. But its underside is that the political engagements of the present override the imagination and investigation of the past. Historicism is a dilemma peculiar to "sexuality" studies in the subcontinent for that reason. As time becomes indistinguishable, so do the plural forms of livelihood and thought in past time. Even oppositional political engagements end by reifying and essentializing identities in general and sexual personalities in particular. One can illustrate this with the various treatments of "sexuality" from within activist-generated historiography itself. A particularly striking instance of this is Ruth Vanita and Saleem Kidwai's Same-Sex Love in India: Readings from Literature and History. The volume was both located in and organized to address the political liberation of Indian gays and lesbians from the homophobic provisions of the colonial Criminal Penal Code of 1861 (revised and adopted by a postcolonial government of India). Many of the code's provisions were used by postcolonial Indian police to trap and punish or blackmail gay men looking for partners, as well as to browbeat lesbian women. However, both this and two subsequent edited volumes on the same themes (Vanita 2002, 2005a) were largely overlooked in both the historical and sociological-anthropological publications that emerged from the North American and British academe at the same time. Thus a recent ethnography of the history and growth of transnational and lesbian communities in North India (Dave 2012) pays as little attention to the Vanita and Kidwai volume as a more conventional history looking for discursive homo- and hetero-sexualities in the Mughal canon (O'Hanlon 2007). The former tracks the genealogy of lesbian 
community-formation in North India from the 1990s, paying particular homage to a solitary transnational figure, Giti Thadani, as the founder of the first lesbian community, and says nothing of Vanita's long presence in North Indian feminist journalism since the 1970s (Vanita 2005a). In a similar vein, O'Hanlon (2007) overlooks the Sultanate and Sufi texts translated by Behl, Kidwai, Kugle, and others in the volume as she developed her picture of Mughal-era regulation of sexualities.

Are these differences driven by a different understanding of "sexuality" per se or are they dependent on attitudes towards governmentality? Since 1999, O'Hanlon had argued that sixteenth-century Sufi courtiers represented the Mughal emperor, Akbar, as the embodiment of perfected sage-the insan-i-kamil-whose cultivation of justice, control, and mastery of the self and the natural world, as well as his renunciation of worldly desires, made him the idealized center of a planetary system made up of orbiting, circumambulating disciple-bodies. Submission to the sage at the center was expressed by willing "service" to him. Such imperial service enhanced the possibilities for moral and human perfection in three homologous worlds that the Akbari disciples were expected to inhabit as governors: the individual human body, the household, and the kingdom.

According to O'Hanlon (2007), this Akbari regime upheld the ideal of heterosexual marriages in order to regulate the conduct of male courtiers and their women while simultaneously discouraging overt "homosexual" attachments of males. The latter were damned by association with the unrestrained appetites of central Asian (Turani, "Transoxania") and Iranian (Irani) male warriors in the subcontinent; Uzbeg courtiers were punished for indulging their "base" appetites. Furthermore, the regulation of male courtier conduct extended to the regulation of courtly and commoner women: sexual activity for women was supposed to be focused for reproduction such that both the very young and the very old were not supposed to be sexually active. Young, unveiled women found in the bazaars and streets or wives who quarreled with their husbands were to be banished to the prostitutes' quarters, which were located outside the imperial city, supervised by wardens and inspectors. Males who wished to patronize prostitutes were required to apply to the wardens and when they failed, the emperor is said to have interviewed the prostitutes directly about their clients, as a consequence of which a number of important courtiers were punished.

O'Hanlon (2007) constructed the genealogy of such Akbari regulations as a combination of akhlaqi literature, thirteenth-century manuals of comportment, the politics of thirteenth- to fifteenth-century Sultans in Northern India, and finally, to the non-Muslim, specifically "Brahmanic" practices of many groups in the subcontinent. Thus she highlighted oath-swearing and ritualistic gestures of obedience, and dietary and sartorial codes adapted from "Brahmanic" societies for the ritual constitution of the Akbari coterie. Members were expected to give alms and submit to a series of regulations devised by the guru cum emperor, such 
as the periodic abstention from meat, avoidance of those involved in its slaughter, and avoidance of sexual relationships with pre-pubertal, elderly, and pregnant women. In the matter of ablutions after sexual intercourse, Akbar bypassed Sunni theological statements on the polluting nature of all emissions of semen and replaced them with an Ayurvedic doctrine on the goodness and purity of sperm.

Yet if much of the Akbari constitution was an effort at establishing a moral authority of an emperor in terms that non-Muslim majorities recognized, then the prohibition of homosocial attachments made little sense either in terms of an Ayurvedic textual tradition or in the erotic manual traditions traceable to Kamasutra-Ratisastra texts. As scholars of these texts and satires had shown, in neither were there blanket prohibitions of "homosocial" attachments or sexually pleasurable actions between men (Doniger and Kakar 2002). Instead, male polymaths and satirists of the eleventh century, such as Ksemendra, had discussed the comparative advantages of a "third gender" (trtiya prakrti) person over a female lover (Baldissera 2009).

Historically attuned ethnomusicologists, aware both of the entire sensorium involved in such strictures and of the training lineages (called gharana, lit. also household) along which all such knowledge passed in the seventeenth century (Schofield 2006, 2012), argue against the reductive reading of "sexuality" in Mughal-era texts. Schofield (2012) insists that erotic encounters with both women and men of lower status were commonplace for noblemen in Mughal society. Socially acceptable codes of masculinity, however, required that the nobleman be the penetrator, not the sexually passive partner; furthermore, they required that the noble male be emotionally distant from the beloved rather than be passionately attached to the object of desire. Training in such comportment was imparted by means of "Mughal courtesan tales," embedded in Mughal chronicles as cautions for male courtiers who had not cultivated perfect self-control. Confronted by the beauty and skill of a female musician and dancer, such a courtier was likely to be maddened by carnal lust (hawa) and lose the struggle of health and intellect to the "base" (nafs) physical body altogether. In Schofield's (2012) reading of the records, the most perfectly skilled women, such as the domni, were those who were asexual virgins or chaste married women whose husbands were similarly skilled dh $a d \bar{h} \imath$, who accompanied them on musical instruments when the vocalists performed in male space. It was their lack of sexual relationships with the Mughal noblemen that enabled the female artistes' spatial mobility between female and male space.

Why then had O'Hanlon $(1999,2007)$ argued that Mughal courtier discourse on desire was to be located within regimes of "hetero" and "homo" sex? It would appear that this interpretation was driven less by an appreciation of Mughal-era Sufi or Ulema sensoria than it was by a modern historian's perspective on the regulatory nature of colonialism. Since 2002-04, Vanita and her cohort accepted that Rekhti’s detailed allusions to relationships of love and friendship between 
courtly Muslim males and their Hindu counterparts, between courtesans and married women, and between Muslim women and Hindu cultural practices were all erased from the canon by colonial-style puritanism and a responsive "reformist" Urdu-writing literati. O'Hanlon, on the other hand, was unwilling to grant the repressive nature of the colonial state, and sought a genealogy of regulations in precolonial Mughal regimes instead. That is where the lines remained drawn: the study of the precolonial past was deeply mired in the postcolonial present.

\section{Conclusion}

What can be learned from this? First, that while ethnographies of the present silence longue durée histories of the subcontinental past, historians of the longue durée precolonial formations are equally likely to silence the discursive densities that encase discussions of embodiment and monastic governmentality in precolonial South Asia. Both simultaneously ignore the formative roles of entire lineages of teachers and disciples who had long studied the human body as the seat of consciousness and generated literary-aesthetic cultures embedding all discourses on "sexuality." Both have likely overlooked the historical fact that only as heads of monastic lineages - as Bodhisattvas in the Burmese, Tibetan, and Mongolian instances—-did "kings" seek to discipline their junior monks and ascetics. Rather than investigate the possibility that Sufi-Ulema courtiers had presented their leader (Akbar) in the light of such "bodhisattva-hood" or that of the "dharma-upholding" cakravartin (moral king), modern feminist historians had been led into the position that the Akbari constitution was about the policing of hetero- and homosexuality.

Apparently, a century-long process of the disappearance and disregard of sets of linguistic and extra-verbal practices (such as that of "intentional languages") and ideals (such as Vaisnava parakiya/adulterous yearning) had also led historians of earlier periods to forget the tools necessary to comprehend the multiple cadences of speech, song, dance, and silence. By the present millennium, both gay and queer feminist historians of the precolonial past had overlooked the monastic-ascetic epistemic and historical possibilities. If the historians themselves could forget, then it was understandable that others did too, especially those who demonized "invisibility" and "silence" in the record as proof of malice on the part of dominant (read "Brahmanic," "patriarchal," or "heterosexist" as necessary) hegemony (John and Nair 1998). What each group thereby reaffirmed was that it had forgotten the history in which vows of silence were once taken, the history in which silence was the mark of cultivated, ritualized speech, and which caused lineages of monastic-ascetic scholars in the seventeenth century to refuse to share their secret medical knowledge with uninitiated non-lineage strangers, the Europeans (Wujastyk 2005). All silences and 
absences from the record were not signs of lack (Arondekar 2009). Many were deliberate evasions. An insistence on baring all in such situations can lead precisely to the opposite of what one intended - the protection of diversity and the pluralism of the landscape.

Only by forgetting monastic governmentality's defeat at the hands of colonialnationalist armies have subcontinental scholar-activists and activism-inspired historians alike furthered the life of a discursive colonization that inheres in the current global rhetoric on "sexuality." The participation of the subcontinental scholars in globalizing this rhetoric further reinforces many old colonial myths: that a Eurocentric dimorphism is indeed a global norm, that upholding such norms is innocent of material economies of space and health, and so on. Such participation by subcontinental scholars also ensures that those older, contentious, monastic-ascetic grammars, epistemes, and ontologies will remain unimagined as honorable forms of being or thought in the past. Furthermore, their sectarian politics and conflicts remain underinvestigated and unincorporated in subcontinental feminist theory. Strictures against such study, on the grounds that such study itself is Orientalist (Puri 1999), may effectively police the reimagination and reinvestigation of the past. It is itself a political stance towards the subcontinent's monastic governmental pasts.

Nor does living in the "Anglo-global present" alone explain the fissiparousness of "sexual" identity politics in the subcontinent. Without fresh investigation of subcontinental monastic schisms, one cannot explain the growth of divisions and disaffections among urban groups of gay and lesbian activists and the rural or urban kothi and hijra lineages (A. Gupta 2005), nor the fractiousness of feminist activism in the subcontinent. Above all, without reimagined pasts, one cannot actually call oneself "postcolonial." If for no other reason but that of labeling such identities correctly, we might reinvestigate the past with new concepts in mind. Perhaps then we might all understand the diverse ways in which our selves have been shrunk to fit puny bodies, and how a discourse of "sexuality" has disciplined scholars and activists alike.

\section{List of References}

Ali, Azra Asghar. 2000. The Emergence of Feminism Among Indian Muslim Women 1920-1947. New Delhi: Oxford University Press.

AlI, DAud. 2006. Courtly Culture and Political Life in Early Medieval India. Cambridge: Cambridge University Press.

Alter, Joseph S. 1997. "Seminal Truth: A Modern Science of Male Celibacy in North India.” Medical Anthropology Quarterly, n.s., 11(3):275-98.

Amin, Sonia Nishat. 1996. The World of Muslim Women in Colonial Bengal 1876-1939. Leiden and New York: E.J. Brill. 
Arondekar, Anjali. 2009. For the Record: On Sexuality and the Colonial Archive in India. Durham, N.C.: Duke University Press.

Arunima, G. 2003. There Comes Papa: Colonialism and the Transformation of Matriliny in Kerala, Malabar c. 1850-1940. Hyderabad: Orient Longman.

Balabanlilar, Lisa. 2010. "The Begims of the Mystic Feast: Turco-Mongol Tradition in the Mughal Harem." Journal of Asian Studies 69(1):123-47.

Baldissera, Fabrizia. 2009. "Telling Bodies." In The Body in India: Ritual, Transgression, Performativity, eds. Alex Michaels and Christopher Wulf, 93-106. Berlin: Akademie Verlag.

Banerjee, Sumanta. 1998. Dangerous Outcast: The Prostitute in Nineteenth-Century Bengal. Calcutta: Seagull Press.

Barnett, Richard B. 1998. "Embattled Begams: Women as Power Brokers in Early Modern India." In Women in the Medieval Islamic World, ed. Gavin R. G. Hambly, 521-36. London: St. Martin's Press.

Benton, Catherine. 2006. God of Desire: Tales of Kamadeva in Sanskrit Story Literature. Albany: State University of New York Press.

Bhattacharya, Tiтhi. 2005. The Sentinels of Culture: Class, Education and the Colonial Intellectual in Bengal (1848-85). New York: Oxford University Press.

Boston Women's Health Boок Collective. 1973. Our Bodies, Ourselves. New York: Simon and Schuster.

Burton, Antoinette, ed. 1999. Gender, Sexuality and Colonial Modernities. London and New York: Routledge.

Cattoi, Thomas, and June McDaniel, eds. 2011. Perceiving the Divine Through the Human Body: Mystical Sensuality. New York: Palgrave Macmillan.

Chakravarti, Uma. 1995. "Wifehood, Widowhood and Adultery: Female Sexuality, Surveillance and State in Eighteenth-Century Maharashtra." Contributions to Indian Sociology 29(3):13-19.

Chatterjee, Indrani. 1999a. Gender, Slavery and the Law. Delhi: Oxford University Press.

1999b. "Colouring Subalternity: Slaves, Concubines and Social Orphans in Early Colonial India." Subaltern Studies 10:49-97.

— ed. 2004. Unfamiliar Relations: Family and History in South Asia. Delhi: Permanent Black; New Brunswick, N.J.: Rutgers University Press.

—. Forthcoming. Forgotten Friends: Monks, Marriages, Memories of Northeast India. Delhi: Oxford University Press.

Chowdhury, Prem. 1994. The Veiled Women: Shifting Gender Equations in Rural Haryana 1880-1990. Delhi: Oxford University Press.

_ 1996. "Contesting Claims and Counter-Claims: Questions of the Inheritance and Sexuality of Widows in a Colonial State." In Social Reform, Sexuality and the State, ed. Patricia Uberoi, 65-82. New Delhi: Sage Publishers.

Cox, Whitney. 2010. "Sharing a Single Seat: The Poetics and Politics of Male Intimacy in the Vikramankavya." Journal of Indian Philosophy 38(5):485-501.

Dehejia, Vidya, and Daryl Y. Harnisch. 1997. "Yoga as the Key to Understanding the Sculpted Body." In Representing the Body: Gender Issues in Indian Art, ed. Vidya Dahejia, 68-81. Delhi: Kali for Women.

Dalrymple, William. 2002. White Mughals: Love and Betrayal in Eighteenth-Century India. New York: Viking.

Das, Rahul Peter. 1992. "Problematic Aspects of the Sexual Rituals of the Bauls of Bengal." Journal of the American Oriental Society 112(3):388-432. 
Dave, Naisargi. 2012. "To Render Real the Imagined: An Ethnographic History of Lesbian Community in India." Signs 35(3):595-619.

Davidson, Ronald M. 2002. Indian Esoteric Buddhism: A Social History of the Tantric Movement. New York: Columbia University Press.

De Mel, Neloufer. 2001. Women and the Nation's Narrative: Gender and Nationalism in Twentieth-Century Sri Lanka. New Delhi: Kali for Women.

Desai, Vishakha N. 1997. "Reflections on the History and Historiography of Male Sexuality in Early Indian Art.” In Representing the Body: Gender Issues in Indian Art, ed. Vidya, Dahejia, 42-55. Delhi: Kali for Women.

Dimock, Edward C. JR. 1966. The Place of the Hidden Moon: Erotic Mysticism in the Vaisnava Sahajiya Cult of Bengal. Chicago: University of Chicago Press.

Doniger (O'Flaherty), Wendy. 1973. Siva: The Erotic Ascetic. New York: Oxford University Press.

Doniger, Wendy, and Sudhir Kakar trans. and eds. 2002. Vatsyana Kamasutra. New York: Oxford University Press.

Fisher, Michael H. 1998. "Women and the Feminine in the Court and High Culture of Awadh, 1722-1856." In Women in the Medieval Islamic World, ed. Gavin R. G. Hambly, 489-520. London: St. Martin's Press.

Flood, Gavin D. 1993. Body and Cosmology in Kashmir Saivism. San Francisco: Edwin Mellen Press.

Foucault, Michel. 1978. The History of Sexuality. New York: Pantheon Books.

Ghosh, Durba. 2006. Sex and the Family in Colonial India: The Making of Empire. Cambridge: Cambridge University Press.

Goswami, Namita. 2008. “Autophagia and Queer Transnationality: Compulsory Heteroimperial Masculinity in Deepa Mehta’s Fire.” Signs 33(2):343-69.

Greer, Germaine. 1970. The Female Eunuch. London: MacGibbon \& Kee.

Gupta, Aloк. 2005. "Englishpur Ki Kothi: Class Dynamics in the Queer Movement in India." In Because I Have a Voice: Queer Politics in India, eds. Arvind Narrain and Gautam Bhan, 123-43. New Delhi: Yoda Press.

Gupta, Charu. 2001. Sexuality, Obscenity, Community: Women, Muslims and the Hindu Public in Colonial India. Delhi: Permanent Black.

Gyatso, Janet. 2003. "One Plus One Makes Three: Buddhist Gender, Monasticism and the Law of the Excluded Middle." History of Religions 43(2):89-115.

Hansen, Kathryn. 1992. Grounds for Play: The Nautanki Theater of North India. Berkeley: University of California Press.

. 1999. "Making Women Visible: Gender and Race, Cross-Dressing in the Parsi Theater." Theater Journal 51(2):127-47.

—. 2004. "Theatrical Transvestism in the Parsi, Gujarati and Marathi Theatres (1850_ 1940)." In Sexual Sites, Seminal Attitudes: Sexualities, Masculinities, and Culture in South Asia, ed. Sanjay Srivastava, 99-122. New Delhi: Sage Publications.

Hawes, Christopher. 1996. Poor Relations: The Making of a Eurasian Community in British India 1773-1833. Richmond, England: Curzon.

Hawley, John S. 1988. Songs of the Saints of India. New York: Oxford University Press. Horswell, Michael J. 2005. Decolonizing the Sodomite: Queer Tropes of Sexuality in Colonial Andean Culture. Austin: University of Texas Press.

John, Mary E., and Janaki NaIr, eds. 1998. A Question of Silence? The Sexual Economies of Modern India. New Delhi: Manohar.

Jordan, Kay K. 2003. From Sacred Servant to Profane Prostitute: A History of the Changing Legal Status of the Devadasis in India, 1857-1947. New Delhi: Manohar. 
Kabeer, Naila. 1985. Organizing Landless Women in Bangladesh. Manchester, England: Oxford University Press.

Kadam, V. S. 1988. "The Institution of Marriage and the Position of Women in Eighteenth-Century Maharashtra." Indian Economic and Social History Review 25(3):350-58.

Kakar, Sudhir. 1989. Intimate Relations: Exploring Indian Sexuality. Chicago: Chicago University Press.

Kakar, Sudhir, and John M. Ross. 1986. Tales of Love, Sex and Danger. Delhi: Oxford University Press.

Karve, Iravati. 1969. Yuganta: The End of an Epoch. Pune: Deshmukh Prakashan.

Kasturi, Malavika. 2009. "Asceticising Monastic Families: Ascetic Genealogies, Property Feuds and Anglo-Hindu Law in Late Colonial India.” Modern Asian Studies 43(5): 1039-83.

Khanna, Akshay. 2005. “Beyond 'Sexuality'(?).” In Because I Have a Voice: Queer Politics in India, eds. Arvind Narrain and Gautam Bhan, 89-103. New Delhi: Yoda Press.

Kugle, Scott A. 2007. Sufis and Saints' Bodies: Mysticism, Corporeality and Sacred Power in Islam. Chapel Hill: University of North Carolina Press.

- 2010. Homosexuality in Islam: Critical Reflections on Gay, Lesbian and Transgender Muslims. Oxford, England: Oneworld Publications.

Kumar, Radha. 1993. The History of Doing: An Illustrated Account of Movements for Women's Rights and Feminism in India 1800-1990. London: Verso.

LaL, Ruby. 2005. Domesticity and Power in the Early Mughal World. Cambridge and New York: Cambridge University Press.

LaL, Vinay. 1999. "Not This Not That: The Hijras of India and the Cultural Politics of Sexuality." Social Text 61:119-40.

Lambert-Hurley, Siobhan, and Avril Powell, eds. 2006. Rhetoric and Reality: Gender and the Colonial Experience in South Asia. New Delhi: Oxford University Press.

Leonard, Karen I. 2011. "Family Firms in Hyderabad: Gujarati, Goswami, and Marwari Patterns of Adoption, Marriage, and Inheritance." Comparative Studies in Society and History 53(4):827-54.

Majumdar, Rochona. 2009. Marriage and Modernity: Family Values in Colonial Bengal. Durham, N.C.: Duke University Press.

Meyer, Johann Jаков. 1971. Sexual Life in Ancient India: A Study in the Comparative History of Indian Culture. Delhi: Motilal Banarsidass.

Minault, Gail. 1998. Secluded Scholars: Women's Education and Muslim Social Reform in Colonial India. New Delhi: Oxford University Press.

— 2009. Gender, Language and Learning: Essays in Indo-Muslim Cultural History. Ranikhet: Permanent Black.

Nadou, Jean. 1980. Buddhists of Kasmir. Delhi: Agam Kala Prakashan.

Nair, Janaki. 1994. "The Devadasi, Dharma and the State." Economic and Political Weekly 29(50):3157-67.

Newbigin, Eleanor. 2010. “A Postcolonial Patriarchy? Representing Family in the Indian Nation-State.” Modern Asian Studies 44(1):121-44.

O’Hanlon, Rosalind. 1999. "Manliness and Imperial Service in Mughal North India." Journal of Economic and Social History of the Orient 42(1):47-93.

—. 2007. "Kingdom, Household and Body History, Gender and Imperial Service under Akbar." Modern Asian Studies 41(5):889-923.

Petievich, Carla. 2007. When Men Speak as Women: Vocal Masquerade in Indo-Muslim Poetry. Delhi: Oxford University Press. 
Pinch, William R. 2006. Warrior Ascetics and Indian Empires. Cambridge: Cambridge University Press.

Poonacha, Veena. 1996. "Redefining Gender Relationships: The Imprint of the Colonial State on the Coorg/Kodava Norms of Marriage and Sexuality." In Social Reform, Sexuality and the State, ed. Patricia, Uberoi, 39-64. New Delhi: Sage Publishers.

Punja, Shobnita. 1992. Divine Ecstasy: The Story of Khajuraho. New York: Viking.

—. 1999. Khajuraho: The First Thousand Years. New York: Viking/Allen Lane.

Puri, Jyoti. 1999. Woman, Body, Desire in Post-colonial India: Narratives of Gender and Sexuality. New York: Routledge.

Ramakrishna, Jayashree, Mani Karott, Radha Srinivasa Murthy, Vinay Chandran, and Pertil J. Pelto. 2004. "Sexual Behaviours of Street Boys and Male Sex Workers in Bangalore." In Sexuality in the Time of AIDS: Contemporary Perspectives from Communities in India, eds. Ravi K. Verma, Pertti J. Pelto, Stephen L. Schensul, and Archana Joshi, 45-67. New Delhi: Sage Publications.

Ramanujan, A. K. 1981. Hymns for the Drowning: Poems for Visnu by Nammalvar. Princeton, N.J.: Princeton University Press.

Ramanujan, A. K., V. N. Rao, and David Shulman, trans. and eds. 1994. When God Is a Customer: Telugu Courtesan Songs by Ksetrayya. Berkeley: University of California Press.

Reddy, Gayatri. 2005. With Respect to Sex: Negotiating Hijra Identity in South India. Chicago: Chicago University Press.

Rege, Sharmila. 1996. "The Hegemonic Appropriation of Sexuality: The Case of the Lavani Performers of Maharashtra." In Social Reform, Sexuality and the State, ed. Patricia, Uberoi, 23-38. New Delhi: Sage Publishers.

Revathi. 2005. “A Hijra’s Own Story.” In Because I Have a Voice: Queer Politics in India, eds. Arvind Narrain and Gautam Bhan, 225-30. New Delhi: Yoda Press.

Samuel, Goeffrey. 2005. Tantric Revisionings: New Understandings of Tibetan Buddhism and Indian Religion. Delhi: Motilal Banarsidass; London: Ashgate.

- 2008. The Origins of Yoga and Tantra: Indic Religions to the Thirteenth Century. Cambridge: Cambridge University Press.

Sarkar, Tanika. 2010. Rebels, Wives, Saints: Designing Selves and Nations in Colonial Times. Calcutta: Seagull Books.

Sawhney, Simona. 2008. The Modernity of Sanskrit. Minneapolis: University of Minnesota Press.

Schofield (Brown), Katherine Butler. 2006. "If Music Be the Food of Love: Masculinity and Eroticism in the Mughal Mehfil." In Love in South Asia: A Cultural History, ed. Francesca, Orsini, 61-86. Cambridge: Cambridge University Press.

—. 2012. "The Courtesan's Tale: Female Musicians and Dancers in Mughal Historical Chronicles, c.1556-1748." Gender and History 24(1):150-71.

Sinha, Mrinalini. 1995. Colonial Masculinity: The 'Manly Englishman' and the 'Effeminate Bengali' in the Late Nineteenth Century. Manchester, England: Manchester University Press.

SonejI, Davesh. 2011. Unfinished Gestures: Devadasis, Memory and Modernity in South India. Chicago: University of Chicago Press.

Sreenivas, Mytheli. 2008. Wives, Widows, Concubines: The Conjugal Family Ideal in Colonial India. Bloomington: Indiana University Press.

Sreenivasan, Ramya. 2006. "Drudges, Dancing Girls, Concubines: Female Slaves in Rajput Polity, 1500-1850." In Slavery and South Asian History, eds. Indrani, Chatterjee and Richard M.Eaton136-61. Bloomington: Indiana University Press. 
- 2007. The Many Lives of a Rajput Queen: Heroic Pasts in India c. 1500-1900. Ranikhet: Permanent Black; Seattle: University of Washington Press.

Srinivasan, Amrit. 1985. "Reform and Revival: The Devadasi and Her Dance." Economic and Political Weekly 20(44):1869-78.

Srivastava, Sanjay, ed. 2004. Sexual Sites, Seminal Attitudes: Sexualities, Masculinities and Culture in South Asia. New Delhi: Sage Publications.

— Delhi: Routledge.

Stoler Miller, Barbara. 1977. Love Song of the Dark Lord. New York: Columbia University Press.

Sweet, Michael J. 2002. "Eunuchs, Lesbians and Other Mythical Beasts: Queering and Dequeering the Kama Sutra." In Queering India: Same-Sex Love and Eroticism in Indian Culture and Society, ed. Ruth Vanita, 77-84. New York: Routledge.

Tambe, Ashwini. 2009. Codes of Misconduct: Regulating Prostitution in Late Colonial Bombay. Minneapolis: University of Minnesota Press.

Thadani, Giti. 1996. Sakhiyani: Lesbian Desire in Ancient and Modern India. London: Cassell.

Uberoi, Patricia, ed. 1996. Social Reform, Sexuality and the State. New Delhi: Sage Publications.

VAnita, Ruth, ed. 2002. Queering India: Same-Sex Love and Eroticism in Indian Culture and Society. New York: Routledge.

— - ed. 2005a. Love's Rite: Same-Sex Marriage in India and the West. London: Palgrave Macmillan.

Vanita, Ruth, ed. 2005b. Gandhi's Tiger and Sita's Smile: Essays on Gender, Sexuality and Culture. New Delhi: Yoda Press.

Vanita, Ruth, and SAleem Kidwai, eds. 2000. Same-Sex Love in India: Readings from Literature and History. New York: St. Martin's Press.

Visram, Rozina. 1986. Ayahs, Lascars and Princes: Indians in Britain 1700-1947. London: Pluto Press.

Walsh, Judith. 2004. Domesticity in Colonial India: What Women Learned When Men Gave Them Advice. New York: Rowman and Littlefield Publishers.

White, David Gordon. 1996. The Alchemical Body: Siddha Traditions in Medieval India. Chicago: Chicago University Press.

—. 2003. Kiss of the Yogini: 'Tantric' Sex in Its South Asian Contexts. Chicago: Chicago University Press.

- 2009. Sinister Yogis. Chicago: Chicago University Press.

Wilson, Kathleen. 2011. "Rethinking the Colonial State: Family, Gender and Governmentality in Eighteenth-Century British Frontiers." American Historical Review 116(5):1294-1322.

Wujastyk, Dominik. 2005. "Change and Creativity in Early Modern Indian Medical Thought.” Journal of Indian Philosophy 33(1):95-118.

- 2009. "Interpreting the Image of the Human Body in Premodern India." International Journal of Hindu Studies 13(2):189-228.

Zafar, Fareeha, ed. 1991. Finding Our Way: Readings on Women in Pakistan. Lahore: Applied Socio-Economic Research.

Zysk, Kenneth G. 2002. Conjugal Love in India: Ratisastra and Ratiraman: Text, Translation and Notes. Leiden: E.J. Brill. 